\title{
DO NECTAR- AND FRUIT-EATING BIRDS HAVE LOWER NITROGEN REQUIREMENTS THAN OMNIVORES? AN ALLOMETRIC TEST
}

\author{
Ella Tsahar, ${ }^{1,4}$ Zeev Arad, $^{1}$ Ido Izhaki, ${ }^{2}$ and Carlos Martínez del Rio ${ }^{3}$ \\ ${ }^{1}$ Department of Biology, Technion-Israel Institute of Technology, Haifa 32000, Israel; \\ ${ }^{2}$ Department of Biology, University of Haifa at Oranim, K. Tivon 36006, Israel; and \\ ${ }^{3}$ Department of Zoology and Physiology, University of Wyoming, Laramie, Wyoming 82071, USA
}

Abstract. - We used an allometric approach to compare the minimum nitrogen requirements (MNR) and the total endogenous nitrogen loss (TENL) of nectar- and fruit-eating birds with those of omnivorous birds. These two parameters were $4 \times$ higher in omnivores than in nectarivores and frugivores. In nectarivorousfrugivorous birds, MNR was $152.8 \mathrm{mg} \mathrm{N} \mathrm{kg}^{-0.76}$ day $^{-1}$; in omnivorous birds, it was $575.4 \mathrm{mg} \mathrm{N} \mathrm{kg}^{-0.76} \mathrm{day}^{-1}$. Similarly, TENL was $54.1 \mathrm{mg} \mathrm{N} \mathrm{kg}^{-0.69}$ day $^{-1}$ in nectarivoresfrugivores, and $215.3 \mathrm{mg} \mathrm{N} \mathrm{kg}^{-0.69}$ day $^{-1}$ in omnivores. The residuals of the allometric relationships between TENL and MNR and body mass were positively correlated, which suggests that a large proportion of the interspecific variation in MNR is explained by variation in TENL. Although our results show that nectar- and fruiteating birds have low nitrogen requirements, the mechanisms that these animals use to conserve nitrogen remain unclear. Received 23 August 2005, accepted 8 November 2005.

Key words: allometry, frugivorous birds, minimum nitrogen requirements, nectarivorous birds, omnivorous birds, phylogeny, total endogenous nitrogen loss.

\section{¿Tienen las Aves Nectrarívoras y Frugívoras Requerimientos de Nitrógeno Menores que} las Omnívoras? Una Prueba Alométrica

\begin{abstract}
Resumen.-Empleamos un enfoque alométrico para comprar los requerimientos mínimos de nitrógeno (RMN) y la pérdida total endógena de nitrógeno (PTEN) de aves nectarívoras y frugívoras con los parámetros observados en aves omnívoras. Los dos parámetros fueron cuatro veces mayores en los omnívoros que en los nectarívoros y frugívoros. En aves nectarívoras y frugívoras, los $\mathrm{RMN}$ fueron de $152.8 \mathrm{mg} \mathrm{N} \mathrm{kg}$ día $^{-1}$, y en las aves omnívoras de $575.4 \mathrm{mg} \mathrm{N} \mathrm{kg}^{-0.76} \mathrm{día}^{-1}$. De modo similar, la PTEN fue de $54.1 \mathrm{mg} \mathrm{N} \mathrm{kg}{ }^{-0.69} \mathrm{día}^{-1}$ en las nectarívoras y frugívoras, y de $215.3 \mathrm{mg} \mathrm{N} \mathrm{kg}^{-0.69} \mathrm{día}^{-1}$ en las omnívoras. Los residuos de las relaciones alométricas entre la PTEN y los RMN y el peso corporal estuvieron correlacionados positivamente, lo que sugiere que una gran parte de la variación interespecífica en los RMN se explica por la variación en la PTEN. Aunque nuestros resultados muestran que las aves que se alimentan de néctar y frutos presentan requerimientos de nitrógeno bajos, los mecanismos que estos animales emplean para conservar el nitrógeno aún no están claros.
\end{abstract}

Nitrogen CAN Be a limiting resource for animals (Mattson 1980, White 1993, Witmer 1998), which require it in the form of essential and nonessential amino acids and for the synthesis

${ }^{4}$ E-mail: elat@techunix.technion.ac.il of other nitrogenous compounds (Klasing 1998). White (1993) provided a large number of examples of animal populations that are limited not by the availability of energy, but by the scarcity of nitrogen. However, not all animals experience nitrogen limitation to the same extent. The amount and quality of protein varies among 
diets (Klasing 1998, Pryor 2003). It is widely believed that the nitrogen needs of animals match their diets' protein content (Witmer 1998, Bosque and Pacheco 2000). Nectar and fruit pulp, for example, contain very low levels of protein (Brice and Grau 1991, Izhaki 1993, Witmer 1998, Gartrell 2000), and several authors have hypothesized that animals that feed on them have low nitrogen requirements (Bosque and Pacheco 2000, Roxburgh and Pinshow 2000, van Tets and Nicolson 2000, McWhorter et al. 2003).

Nitrogen requirements are traditionally estimated by two parameters: minimum nitrogen requirements (MNR) and total endogenous nitrogen loss (TENL). The latter estimates the nitrogen losses on nitrogen-free diets, whereas the former estimates the amount of nitrogen required to achieve nitrogen balance (i.e., intake equals excretion). Minimum nitrogen requirements and TENL are useful comparative tools that estimate the nitrogen requirements of animals that are not growing and that are nonreproductive (Klasing 1998). The most widely used method to measure MNR and TENL is to feed birds diets that share the same ingredients and differ only in their protein content. Typically, nitrogen balance (the difference between nitrogen intake and total excreted nitrogen) and intake are related by a linear function. Thus, TENL is estimated as the $y$-intercept of this function, which represents the nitrogen losses when the animal is ingesting no protein. Minimum nitrogen requirement is estimated by calculating the $x$-intercept of this function, when presumably animals are in nitrogen balance and ingest as much nitrogen as they lose (Brice and Grau 1991, Korine et al. 1996, Witmer 1998, Allen and Hume 2001, Roxburgh and Pinshow 2000, Pryor et al. 2001).

Both MNR and TENL are functions of body mass. Robbins (1993) found that the scaling exponent of these allometric relationships was $\sim 0.75$ and established two predictive relationships that are widely used. He estimated that MNR and TENL equal $430 \mathrm{mg} \mathrm{N} \mathrm{kg}^{-0.75}$ day $^{-1}$ and $270 \mathrm{mg} \mathrm{N} \mathrm{kg}^{-0.75}$ day $^{-1}$, respectively. To examine whether Robbins's (1993) estimates apply to nectarivorous and frugivorous birds and to test the hypothesis that the $\mathrm{N}$ requirements of these animals are lower than those of omnivores, we compiled and analyzed available data on the MNR and TENL of various avian species. The data in our analyses originated from studies that satisfied two criteria: (1) the studied birds were not growing or reproducing, and (2) the study was designed to explicitly measure MNR and TENL (Table 1). In addition to conducting a standard regression analysis, we compared the nitrogen requirements of nectarivorous and frugivorous birds with those of omnivores using a qualitative, but phylogenetically explicit, comparison. Our results verified that MNR and TENL both scale with body mass to the 0.75 power and confirmed the hypothesis that nectarivorous and frugivorous birds have relatively low nitrogen requirements.

\section{Methods}

Because MNR and TENL are related to body mass by a power function, we log-transformed all data before analysis. We used a linear model to assess whether the relationship between log body mass and $\log$ MNR and log TENL differed between nectarivores and frugivores. We found that these relationships did not differ in either intercept (MNR: $F=0.004, \mathrm{df}=1$ and 10; TENL: $F=0.0068, \mathrm{df}=1$ and $10 ; P>0.5$ ) or slope (MNR: $F=0.53, \mathrm{df}=1$ and 10; TENL: $F=2.4, \mathrm{df}=1$ and $10 ; P>0.2)$. Thus, we pooled nectarivorous and frugivorous birds into a single category. Our phylogenetic comparison was based on Sibley and Ahlquist's (1991) DNA-DNA hybridization phylogenetic hypothesis. Relationships among hummingbird species were obtained from Schondube and Martínez del Rio (2004). Because the number of species in our analysis was small and taxonomically biased (Table 1), a proper phylogenetic analysis, such as phylogenetically independent contrasts (Felsenstein 1985, Garland and Ives 2000), was impossible. Our sample is taxonomically biased (e.g., 6 of the 11 species of nectar-feeding birds are hummingbirds) and, thus, the traits in question are clumped within the phylogeny. Under these conditions, available phylogenetic methods have low power (see Schondube et al. 2001). Thus, we conducted only a qualitative, phylogenetically informed comparison. The purpose of this comparison was to assess whether nectarivorous-frugivorous birds have lower TENL and MNR than the most closely related clades for which information is available. A proper statistical analysis that includes phylogeny must await a more evenly distributed sampling of taxa. 


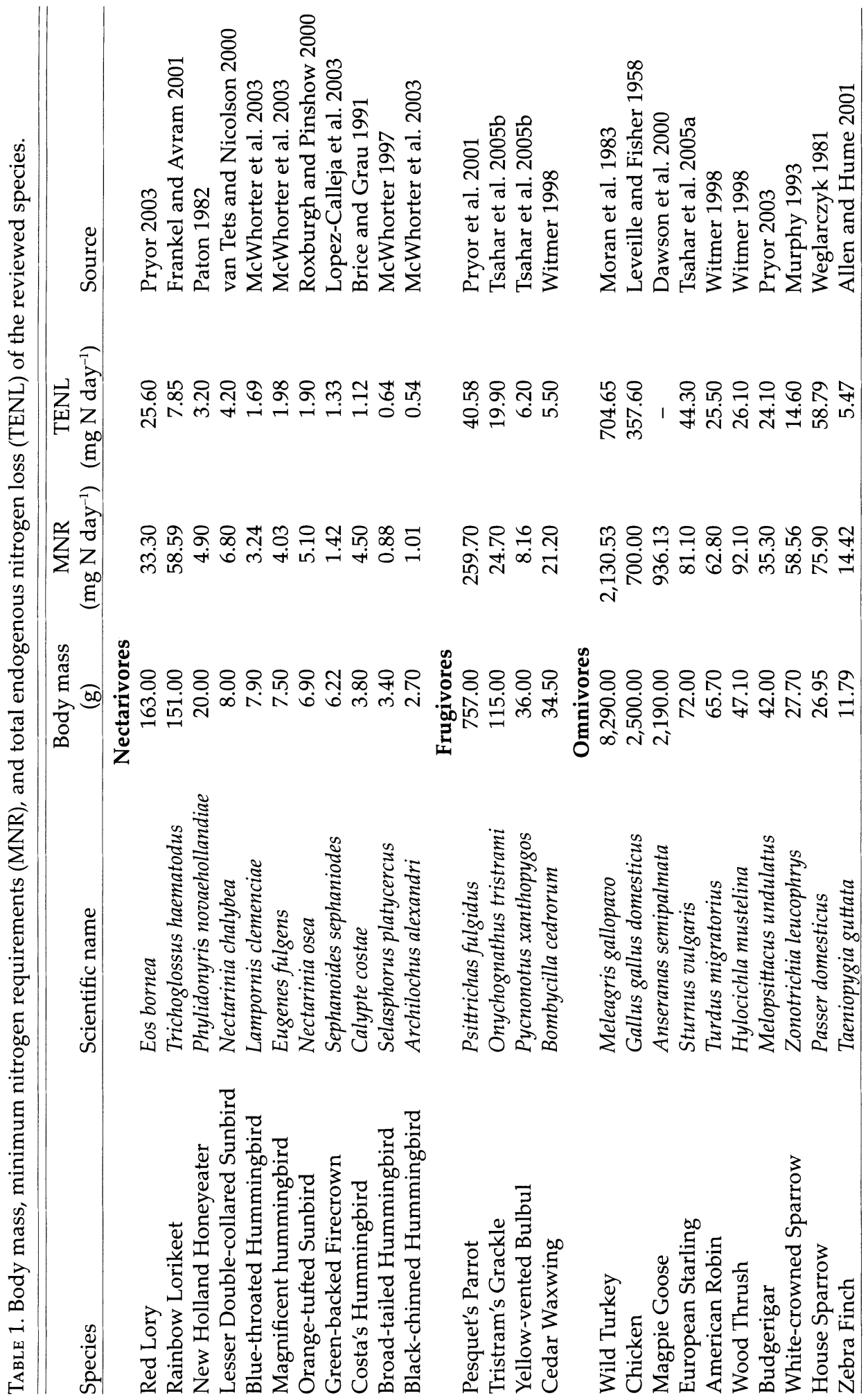




\section{Statistics}

We used a linear model to compare the relations of (1) log body mass to log MNR and (2) $\log$ TENL of nectarivorous-frugivorous birds to that of omnivorous birds. The linear model used in the analysis was $y=\beta_{0}+\beta_{1} x_{1}+\beta_{2} x_{2}+$ $\beta_{3} x_{1} x_{2}+\varepsilon$, where $y$ is the dependent variable (log of either MNR or TENL), $x_{1}$ is log body mass, $x_{2}$ is a dummy variable that represents the effect of guild (omnivore vs. nectarivore-frugivore), $\beta_{0}$ the intercept for omnivores, $\beta_{1}$ the slope for omnivores, $\beta_{2}$ the difference between the intercepts of the guilds and $\beta_{3}$ the difference between their slopes. If $\beta_{3}$ was not statistically different from zero, we dropped this interaction term from the analysis and calculated a reduced model. To test whether TENL and MNR are related, we correlated the residuals of the loglog relationships between these measurements and body mass. Data are reported as means \pm SE. Scientific names of all species reviewed are given in Table 1.

\section{Results}

Both MNR and TENL increased as a function of body mass (Fig. 1). Log MNR was closely and linearly related to log body mass $(F=224.94$, $\mathrm{df}=1$ and $21, P<0.001$ ). We found a significant difference in the intercept of the relationship between log body mass and log MNR between omnivorous and nectarivorous-frugivorous birds $(F=36.11$, df $=1$ and $21, P<0.001)$. However, we found no significant differences in the slope $(F=3.30, \mathrm{df}=1$ and $21, P>0.10)$. Therefore, we eliminated the interaction term of the model and recalculated a common slope. We found that its value equaled $0.76 \pm 0.06$ (Fig. 1). Similarly, we found that the relationship between $\log$ body mass and log TENL was linear $(F=189.88, \mathrm{df}=1$ and $21, P<0.001)$ and that the intercept of this relationship differed significantly between omnivores and nectarivores-frugivores $(F=44.99, \mathrm{df}=1$ and 21, $P<0.001)$. We also found that the slopes of this relationship did not differ between these two groups $(F=0.74, \mathrm{df}=1$ and $21, P>0.20)$. After the interaction term was removed, the common slope equaled $0.69 \pm 0.05$ (Fig. 1), which is not significantly different from $0.75(t=1.2$, $P>0.3)$. Minimum nitrogen requirements and TENL were $\sim 4 \times$ higher in omnivorous than in

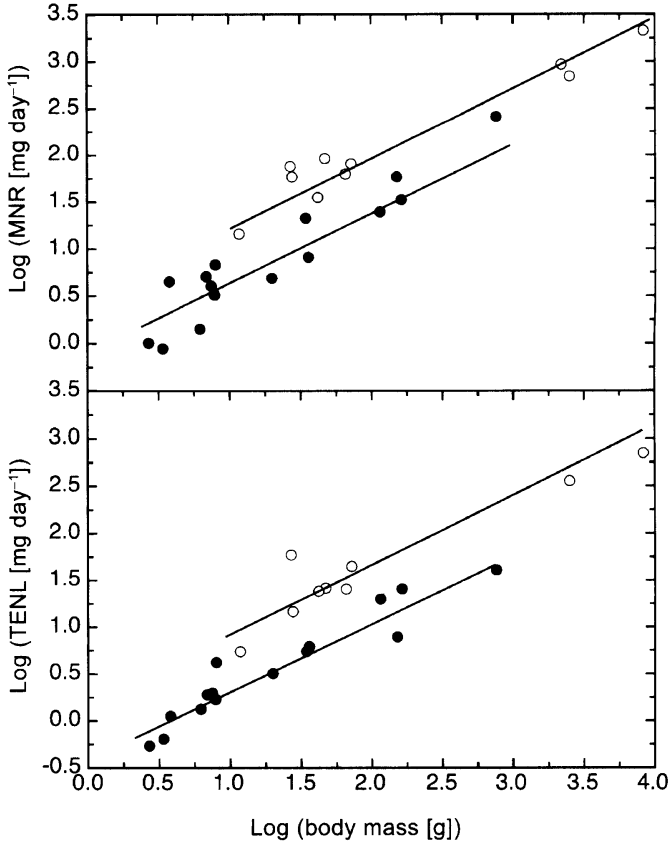

Fig. 1. Both minimum nitrogen requirements (MNR; upper panel) and total endogenous nitrogen loss (TENL; lower panel) increase as a function of body mass, and both are $\sim 4 \times$ higher in omnivores (empty circles; logMNR = $0.48+0.76 \log \mathrm{BM}, \log \mathrm{TENL}=0.26+0.69 \log \mathrm{BM})$ than in nectarivores-frugivores (filled circles; $\log \mathrm{MNR}=-0.096+0.76 \log \mathrm{BM}, \log \mathrm{TENL}=-0.34+$ $0.69 \log \mathrm{BM})$.

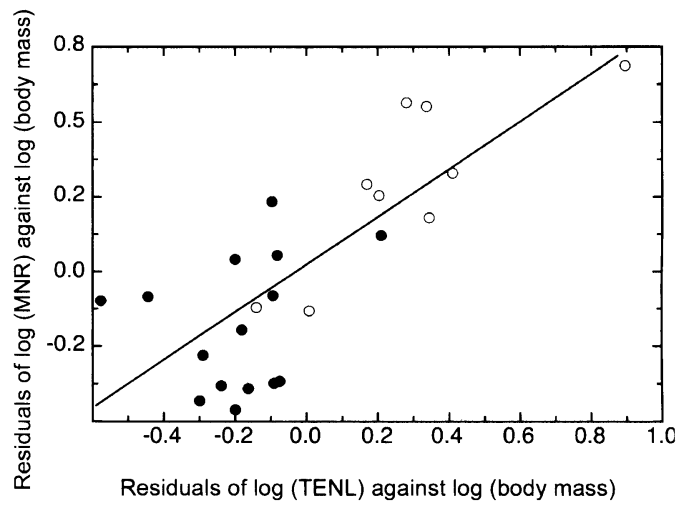

FIg. 2. Residuals of the allometric relationships between TENL and MNR on body mass are positively related $(y=0.800 x-0.002$, $r^{2}=0.61, P<0.0001$; empty circles $=$ omnivores, filled circles $=$ nectarivores-frugivores) . 
nectarivorous-frugivorous birds. The residuals of the allometric relationships between TENL and MNR and body mass were positively and linearly related $(F=33.86, \mathrm{df}=1$ and $22, P<$ 0.0001 ; Fig. 2). This relationship suggests that the MNR increases with TENL when both parameters are standardized for body mass. The phylogenetic tree in Figure 3 illustrates that, in all cases, the MNR of the frugivorous and the nectarivorous clades were lower than that of the most closely related omnivorous species.

\section{Discussion}

Nitrogen requirements of nectarivorous and frugivorous birds, as estimated by MNR and TENL, seem to be $\sim 25 \%$ that of omnivorous birds. Although the allometric relationships between MNR and TENL and body mass differ between these two groups, the exponents of these relationships are similar and do not differ from 0.75 . Our estimates for omnivores are only slightly different from Robbins's (1993) values (Table 2).

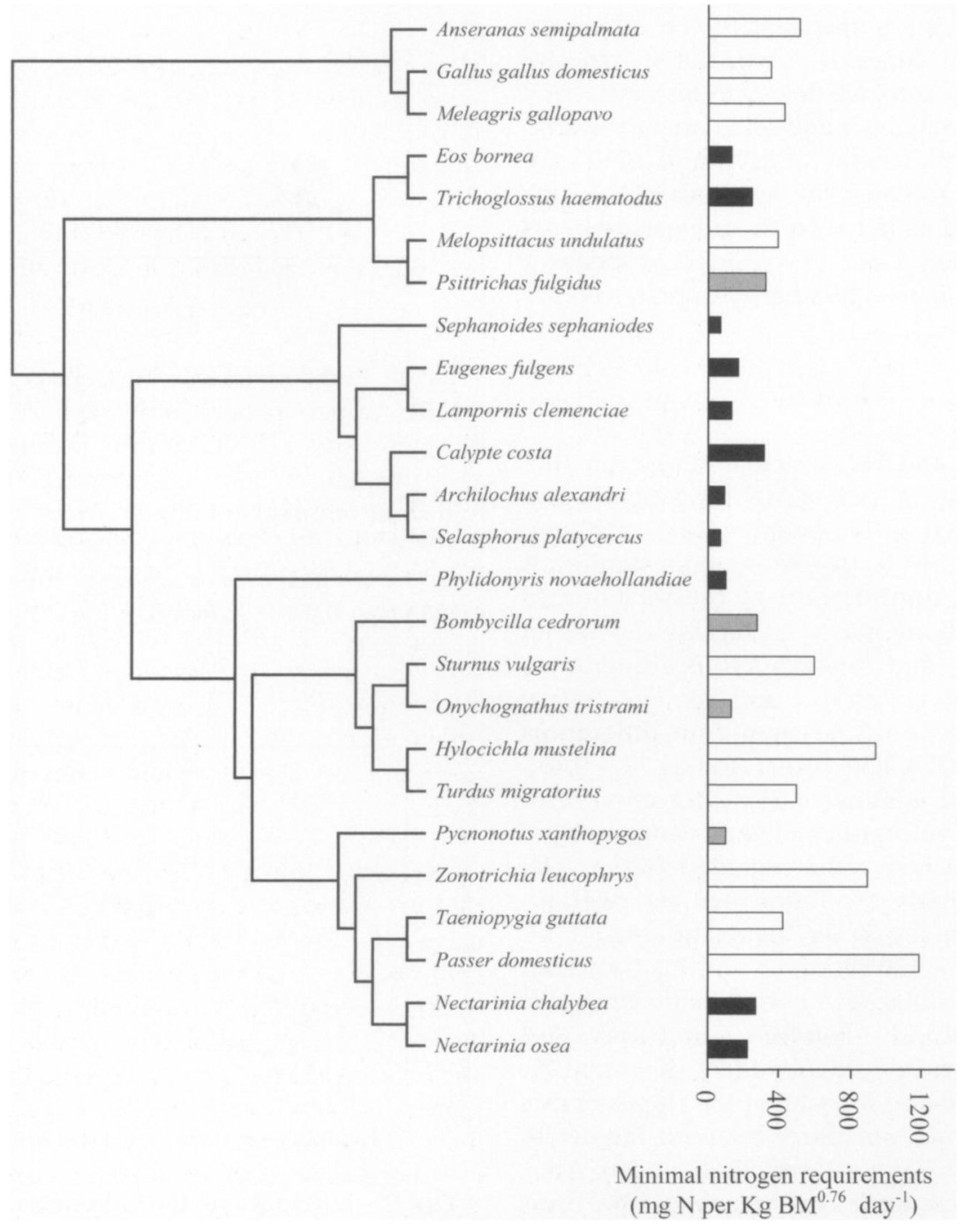

FIG. 3. Mass-specific nitrogen requirements of nectar-eating birds (black bars) and fruit-eating birds (gray bars) are lower than those of omnivorous species (white bars) in the most closely related clades for which data are available. 
TABLE 2. Minimal nitrogen requirements (MNR) and total endogenous nitrogen losses (TENL) of nectar- and fruit-eating birds are lower than those of omnivores. The allometric values estimated with a larger species sample of omnivores are slightly different from those estimated by Robbins (1993). Robbins (1993) estimated TENL and MNR as 270 and $430 \mathrm{mg}$ $\mathrm{kg}^{-0.75}$ day $^{-1}$, respectively.

\begin{tabular}{lcc}
\hline & $\begin{array}{c}\mathrm{TENL} \\
\left(\mathrm{mg} \mathrm{kg}^{-0.69}\right. \\
\left.\mathrm{day}^{-1}\right)\end{array}$ & $\begin{array}{c}\mathrm{MNR} \\
\left(\mathrm{mg} \mathrm{kg}^{-0.76}\right. \\
\left.\mathrm{day}^{-1}\right)\end{array}$ \\
\hline Nectarivores-frugivores & 54.1 & 152.8 \\
Omnivores & 215.3 & 575.4 \\
\hline
\end{tabular}

The large differences in TENL and MNR between omnivores and nectarivores-frugivores emphasize the need to recognize that specialization on different diets is accompanied by differences in nitrogen requirements. Although our phylogenetic comparison is based on a limited number of clade comparisons, it supports the notion that nectarivorous-frugivorous birds have lower nitrogen requirements than omnivorous birds. It also suggests, albeit tentatively, that low nitrogen requirements evolved concurrently with the habit of feeding on nectar or fruit and, hence, with the need to cope with low-protein diets.

Although the ultimate evolutionary causes for the low nitrogen requirements of nectarivorous-frugivorous birds appear to be clear, the proximate physiological mechanisms that allow these animals to subsist on lowprotein diets are neither fully understood nor well studied. A possibility is that the low nitrogen requirements of nectarivorous-frugivorous birds are not the result of their physiological traits but a direct consequence of the characteristics of their diets. The positive relationship between MNR and TENL illustrated in Figure 2 suggests that a large proportion of the interspecific variation in MNR is explained by variation in TENL. There are two components of TENL: endogenous urinary nitrogen losses (EUNL) and metabolic fecal nitrogen (MFN) (Robbins 1993). Nectar and fruit are characterized by low contents of protein, lipids, and fibers. Hence, assimilating their nutrients does not require the secretion of pancreatic enzymes and bile acids (Bosque and Pacheco 2000). These products contain most of the nitrogen lost as MFN (Robbins 1993). Thus, one possible explanation for the low nitrogen requirements of nectarivorous-frugivorous birds is that their diets reduce the loss of metabolic fecal nitrogen (MFN).

Indeed, low MFN losses seem to be prevalent among nectar- and fruit-eating vertebrates. Delorme and Thomas $(1996,1999)$ found low MFN losses in fruit bats (Carollia perspicillata, Artibeus jamaicensis, and Rousettus aegyptiacus), and Smith and Green (1987) found low values in sugar gliders (Petaurus breviceps). McWhorter et al. (2003) reported that $95 \%$ of all the nitrogen excreted by hummingbirds was in the form of urinary nitrogen (urate, ammonia, urea, and creatinine). To test whether the diet per se was a determinant of nitrogen requirements, Tsahar et al. (2005a) measured the nitrogen requirements of the omnivorous European Starling, fed on nectar-like diets (water, sugars, and a low level of protein). They found that the MNR and TENL of these birds were indistinguishable from those expected for an omnivorous species. They also found that, as with hummingbirds, urinary nitrogen, rather than fecal nitrogen, was the major vehicle of nitrogen losses in European Starlings. They concluded that a nectar-like fluid diet, by itself, does not significantly decrease the nitrogen requirements of omnivores. Although nectar and fruit diets can contribute to the low nitrogen requirements of nectarivores and frugivores, they cannot fully explain them.

The observation that metabolic fecal nitrogen represents only a small fraction of the total endogenous nitrogen losses in nectarivorous-frugivorous birds points to urinary nitrogen loss as the primary determinant of their nitrogen requirements. Why should nectarivorous-frugivorous birds have low endogenous urinary nitrogen losses? Factors that can decrease EUNL include low rates of protein turnover, high rates of metabolic nitrogen recycling, and a high capacity for digestive nitrogen recycling (Witmer 1998, Pryor et al. 2001). We make a distinction between metabolic and digestive recycling to recognize that each of these processes is explained by different physiological mechanisms. By "metabolic recycling" we refer to the reuse of nitrogen derived from the catabolism of amino acids to synthesize dispensable amino acids (see Carleton and Martínez del Rio 2005). Protein turnover and metabolic nitrogen recycling have not been investigated from a comparative perspective in 
nectarivorous-frugivorous birds. They remain potentially important mechanisms that can explain the low nitrogen requirements of these animals.

Digestive $\mathrm{N}$ recycling involves the breakdown of urinary $\mathrm{N}$ (urate, urea, or both) by microorganisms that thrive in the gastrointestinal tract, followed by either absorption of liberated ammonia or assimilation of protein synthesized by these microorganisms (Karasawa et al. 1988, Karasawa and Maeda 1995, Karasawa 1999). Preest et al. (2003) reported bacteria with uricase activity in the gastrointestinal tract of Anna's Hummingbirds (Calypte anna), and Roxburgh and Pinshow (2002) and Tsahar et al. $(2005 \mathrm{~b})$ found post-renal urine modification in the nectarivorous Orange-tufted Sunbird and in the frugivorous Yellow-vented Bulbul, respectively. In both of these species, when birds ingested diets with a high water content and a low protein content, the proportion of nitrogen excreted as urate decreased and that of ammonia increased in excreta but not in ureteral urine. Tsahar et al. (2005b) speculated that post-renal urine modification could result from bacterial degradation. Although these observations are suggestive of digestive nitrogen recycling in nectarivorous-frugivorous birds, they do not constitute proof of its quantitative importance.

Digestive recycling by bacteria is physiologically important in avian species with large cecae and, hence, with a well-developed gastrointestinal microbiota (Mortensen and Tindall 1981; Campbell and Braun 1986; Karasawa et al. 1988, 1993; Son and Karasawa 2000). However, most nectarivorous-frugivorous birds have only vestigial cecae. Hummingbirds, arguably the most specialized avian nectarivores, have no cecae (Clench 1999). Therefore, it seems that the gastrointestinal tracts of birds that feed on fruit or nectar do not have the structure: needed to house the large microbiota presumably required for effective digestive nitrogen recycling. The contribution of bacteria to the nitrogen balance of nectarivorous-frugivorous birds remains to be demonstrated.

Another mechanism that may contribute to digestive nitrogen recycling is the reabsorption of amino acids from the lower gut. Many bird species propel ureteral urine upwards in the intestine and, thus, place it in contact with the epithelial surface of the hindgut, which can express significant levels of membrane-bound peptidases (Witmer and Martínez del Rio [2001] and references therein). Uric acid in birds is excreted as a component of spheres that also contain protein and inorganic ions (Casotti and Braun 1997, Goldstein and Skadhauge 2000). It may be that nectar- and fruit-eating birds are capable of assimilating the protein within these spheres. This mechanism may explain post-renal urine modification found in the frugivorous Yellow-vented Bulbul, in which concentration of protein was $3 \times$ higher in ureteral urine than in excreta (Tsahar et al. 2005b). The long microvilli found in the lower gut of Pesquet's Parrots (Guntert 1981, as cited in Pryor et al. 2001), and other nectar- and fruit-eating birds (Witmer and Martínez del Rio 2001), could enhance the recovery of excreted protein.

In summary, although our results support the notion that nectarivorous-frugivorous birds have low nitrogen requirements, we cannot yet offer an adequate mechanistic explanation for why these requirements are as low as they are. We hypothesize that a combination of low protein turnover and high metabolic nitrogen recycling explain why avian nectarivores and frugivores can rely on their remarkably proteinpoor diets.

\section{ACKNOWLEDGmenTS}

This research was supported by the J. S. Frankford Research Fund and by the J. and A. Taub Biological Research Fund from the Technion-Israel Institute of Technology, and by a National Science Foundation grant (IBN0110416) to C.M.R. We thank two anonymous reviewers for their constructive comments.

\section{Literature Cited}

Allen, L. R., And I. D. Hume. 2001. The maintenance nitrogen requirement of the Zebra Finch Taeniopygia guttata. Physiological and Biochemical Zoology 74:366-375.

Bosque, C., ANd M. A. Pacheco. 2000. Dietary nitrogen as a limiting nutrient in frugivorous birds. Revista Chilena de Historia Natural 73:441-450.

Brice, A. T., and C. R. Grau. 1991. Protein requirements of Costa's Hummingbirds Calypte costae. Physiological Zoology 64: 611-626. 
Campbell, C. E., and E. J. Braun. 1986. Cecal degradation of uric acid in Gambel Quail. American Journal of Physiology 251:R59-R62.

Carleton, S. A., and C. Martínez del Rio. 2005. The effect of cold-induced increased metabolic rate on the rate of ${ }^{13} \mathrm{C}$ and ${ }^{15} \mathrm{~N}$ incorporation in House Sparrows (Passer domesticus). Oecologia 144:226-232.

Casotti, G., and E. J. Braun. 1997. Ionic composition of urate-containing spheres in the urin $\rightarrow \rightarrow$ of domestic fowl. Comparative Biochemistry and Physiology 118A:585-588.

$\rightarrow$ Clench, M. H. 1999. The avian cecum: Update and motility review. Journal of Experimenta Zoology 283:441-447.

$\rightarrow$ Dawson, T. J., P. J. Whitehead, A. McLean, F. D. Fanning, and W. R. Dawson. 2000. Digestive function in Australian Magpi $\rightarrow$ KarasawA, Y., T. ONo, And K. KoH. 1993. Geese (Anseranas semipalmata). Australian Journal of Zoology 48:265-279.

$\rightarrow$ Delorme, M., and D. W. Thomas. 1996. Nitrogen and energy requirements of the short-tailed fruit bat (Carollia perspicillata): Fruit bat: are not nitrogen constrained. Journal of Comparative Physiology B 166:427-434.

$\rightarrow$ Delorme, M., and D. W. Thomas. 1999. Comparative analysis of the digestive efficiency and nitrogen and energy requirements of the phyllostomid fruit-bat (Artibeus jamaicensis) and the pteropodid fruit-bat (Rousettu: $\rightarrow$ aegyptiacus). Journal of Comparative Physiology B 169:123-132.

$\rightarrow$ Felsenstein, J. 1985. Confidence limits on phylogenies: An approach using the bootstrap. Evolution 39:783-791.

$\rightarrow$ Frankel, T. L., and D. Avram. 2001. Protein requirements of Rainbow Lorikeets, Trichoglossus haematodus. Australian Journal of Zoology 49:435-443.

$\rightarrow$ Garland, T., JR., AND A. R. Ives. 2000. Using the past to predict the present: Confidenct intervals for regression equations in phylogenetic comparative methods. American Naturalist 155:346-364.

$\rightarrow$ Gartrell, B. D. 2000. The nutritional, morphologic, and physiologic bases of nectar ivory in Australian birds. Journal of Avian Medicine and Surgery 14:85-94.

Goldstein, D. L., ANd E. Skadhauge. 2000. Renal and extrarenal regulation of body fluid composition. Pages 265-297 in Sturkie's Avian Physiology, 5th ed. (G. C. Whittow, Ed.). Academic Press, San Diego, California.
Guntert, M. 1981. Morphologische Untersuchungen zur adaptiven Radiation des Verdauungstraktes bei Papageien (Psittaci). Zoologisches Jahrbuch der Anatomie 106: 471-526.

IzHAKI, I. 1993. Influence of nonprotein nitrogen on estimation of protein from total nitrogen in fleshy fruits. Journal of Chemical Ecology 19:2605-2615.

Karasawa, Y. 1999. Significant role of the nitrogen recycling system through the ceca occurs in protein-depleted chickens. Journal of Experimental Zoology 283:418-425.

Karasawa, Y., M. OKamoto, and H. Kawai. 1988. Ammonia production from uric acid and its absorption from the caecum of the cockerel. British Poultry Science 29:119-124. Relationship of decreased caecal urease activity by dietary penicillin to nitrogen utilisation in chickens fed on a low protein diet plus urea. British Poultry Science 35:91-96.

Karasawa, Y., and M. Maeda. 1995. In situ degradation and absorption of $\left({ }^{15} \mathrm{~N}\right)$ urea in chicken ceca. Comparative Biochemistry and Physiology 111A:223-227.

Klasing, K. C. 1998. Comparative Avian Nutrition. CAB International, Wallingford, United Kingdom.

Korine, C., Z. Arad, and A. Arieli. 1996. Nitrogen and energy balance of the fruit bat Rousettus aegyptiacus on natural fruit diets. Physiological Zoology 69:618-634.

Leveille, G. A., AND H. Fisher. 1958. The amino acid requirements for maintenance in the adult rooster. I. Nitrogen and energy requirements in normal and proteindepleted animals receiving whole egg protein and amino acid diets. Journal of Nutrition 66:441-453.

López-Calleja, M. V., M. J. Fernández, and F. Bozinovic. 2003. The integration of energy and nitrogen balance in the hummingbird Sephanoides sephaniodes. Journal of Experimental Biology 206:3349-3359

Mattson, W. J., JR. 1980. Herbivory in relation to plant nitrogen content. Annual Review of Ecology and Systematics 11:119-161.

MCWhorter, T. J. 1997. Energy assimilation, protein balance, and water absorption in Broad-Tailed Hummingbirds, Selasphorus platycercus. M.S. thesis, University of Wyoming, Laramie. 
McWhorter, T. J., D. R. Powers, and C. Martínez del Rio. 2003. Are hummingbirds facultatively ammonotelic? Nitrogen excretion and requirements as a function of body size. Physiological and Biochemical Zoology 76:731-743.

Moran, E. T., P. R. Ferket, and J. R. Blackman. 1983. Maintenance nitrogen requiremen of the turkey breeder hen with an estimate of associated essential amino acid needs. Poultry Science 62:1823-1829.

$\rightarrow$ Mortensen, A., AND A. R. Tindall. 1981. Caecal decomposition of uric acid in cap $\rightarrow$ SoN tive and free ranging Willow Ptarmigan (Lagopus lagopus lagopus). Acta Physiolgica Scandinavica 111:129-133.

$\rightarrow$ Murphy, M. E. 1993. The protein requirement for maintenance in the White-crowned Sparrow, Zonotrichia leucophrys gambelii Canadian Journal of Zoology 71:2111-2120.

$\rightarrow$ Paton, D. C. 1982. The diet of the New Holland Honeyeater, Phylidonyris novaehollandiae. Australian Journal of Ecology 7:279-298.

$\rightarrow$ Preest, M. R., D. G. Folk, and C. A. Beuchat. 2003. Decomposition of nitrogenous com pounds by intestinal bacteria in hummingbirds. Auk 120:1091-1101.

$\rightarrow$ Pryor, G. S. 2003. Protein requirements of three species of parrots with distinct dietary specializations. Zoo Biology 22:163-177.

$\rightarrow$ Pryor, G. S., D. J. Levey, and E. S. Dierenfeld. 2001. Protein requirements of a specialized frugivore, Pesquet's Parrot (Psittrichas fulgidus). Auk 118:1080-1088.

Robisns, C. T. 1993. Wildlife Feeding and Nutrition, 2nd ed. Academic Press, San Diego, California.

$\rightarrow$ Roxburgh, L., ANd B. Pinshow. 2000. Nitrogen requirements of an Old World nectarivore, the Orange-tufted Sunbird Nectarinia osea Physiological and Biochemical Zoology 73: 638-645.

Roxburgh, L., ANd B. Pinshow. 2002. Ammonotely in a passerine nectarivore: The influence of renal and post-renal modification on nitrog enous waste product excretion. Journal of Experimental Biology 205:1735-1745.

$\rightarrow$ Schondube, J. E., L. G. Herrera M., and C. Martínez del Rio. 2001. Diet and the evolution of digestion and renal function in phyllostomid bats. Zoology 104:59-73.

$\rightarrow$ Schondube, J. E., ANd C. Martínez del Rio. 2004. Sugar and protein digestion in flowerpiercers and hummingbirds: A comparative test of adaptive convergence. Journal of Comparative Physiology B 174:263-273.

Sibley, C. G., ANd J. E. Ahlquist. 1991. Phylogeny and Classification of Birds: A Study in Molecular Evolution. Yale University Press, New Haven, Connecticut.

Smith, A. P., ANd S. W. Green. 1987. Nitrogen requirements of the sugar glider (Petaurus breviceps), an omnivorous marsupial, on a honey-pollen diet. Physiological Zoology 60:82-92.

Son, J. H., and Y. Karasawa. 2000. Effect of removal of caecal contents on nitrogen utilisation and nitrogen excretion in caecally ligated chickens fed on a low protein diet supplemented with urea. British Poultry Science 41:69-71.

Tsahar, E., C. Martínez del Rio, Z. Arad, J. P. Joy, AND I. IzHAKI. 2005a. Are the low protein requirements of nectarivorous birds the consequence of their sugary and watery diet? A test with an omnivore. Physiological and Biochemical Zoology 78:239-245.

Tsahar, E., C. Martínez del Rio, I. Izhaki, and Z. Arad. 2005b. Can birds be ammonotelic? Nitrogen balance and excretion in two frugivores. Journal of Experimental Biology 208: 1025-1034.

$\rightarrow$ van Tets, I. G., And S. W. Nicolson. 2000. Pollen and the nitrogen requirements of the Lesser Double-collared Sunbird. Auk 117:826-830.

WeglarczyK, G. 1981. Nitrogen balance and energy efficiency of protein deposition of the House Sparrow Passer domesticus (L.). Ekologia Polska 29:519-533.

White, T. C. R. 1993. The Inadequate Environment: Nitrogen and the Abundance of Animals. Springer-Verlag, New York.

Witmer, M. C. 1998. Ecological and evolutionary implications of energy and protein requirements of avian frugivores eating sugary diets. Physiological Zoology 71: 599-610.

Witmer, M. C., and C. Martínez del Rio. 2001. The membrane-bound intestinal enzymes of Cedar Waxwings and thrushes. Physiological and Biochemical Zoology 74: 584-593.

Associate Editor: G. R. Bortolotti 